\title{
Catalytic Activity of Halogenated Iron Porphyrins in Alkene and Alkane Oxidations by Iodosylbenzene and Hydrogen Peroxide
}

\author{
André Aparecido Guedes ${ }^{a}$, John R. L. Smith ${ }^{b}$, Otaciro R. Nascimento ${ }^{c}$ Débora F. Costa Guedes ${ }^{a}$ and \\ Marilda das Dores Assis ${ }^{*, a}$ \\ ${ }^{a}$ Departamento de Química, Faculdade de Filosofia Ciências e Letras de Ribeirão Preto, Universidade de São Paulo, \\ Av. Bandeirantes, 3900, 14040-901 Ribeirão Preto - SP, Brazil \\ ${ }^{b}$ Department of Chemistry, University of York, York, UK Y010 5DD \\ ${ }^{c}$ Departamento de Física, Instituto de Física Quântica de São Carlos, Universidade de São Paulo,
} CP 396, 13560-905 São Carlos - SP, Brazil

\begin{abstract}
Uma ferro porfirina poli-clorada, $\mathrm{Fe}\left(\mathrm{PCl}_{8}\right) \mathrm{Cl}$, foi sintetizada e usada como catalisador em reações de oxidação de hidrocarbonetos por iodosilbenzeno e peróxido de hidrogênio, em solução e ancorado covalentemente na aminopropilsilica. Embora a $\mathrm{Fe}\left(\mathrm{PCl}_{8}\right) \mathrm{Cl}$ tenha mostrado a mesma eficiência da ferro porfirina precursora, $\mathrm{Fe}(\mathrm{P}) \mathrm{Cl}$, na epoxidação de alcenos, foi um catalisador mais eficiente na hidroxilação de alcanos por iodosilbenzeno, com preferência por carbonos secundários na oxidação do adamantano e primário na oxidação do pentano. Essa seletividade reflete o impedimento estéreo da espécie ferro-oxo ou, alternativamente, a grande reatividade do oxidante ativo gerado da $\mathrm{Fe}\left(\mathrm{PCl}_{8}\right) \mathrm{Cl}$. $\mathrm{A} \mathrm{Fe}\left(\mathrm{PCl}_{8}\right) \mathrm{Cl}$ ancorada mostrou baixa atividade catalítica quando comparada com o catalisador homogêneo e com a $\mathrm{Fe}(\mathrm{P}) \mathrm{Cl}$ ancorada. Peróxido de hidrogênio foi um oxidante pobre para este sistema. A excessiva substituição dos hidrogênios por grupos sacadores de elétrons na periferia do anel porfirínico dificulta a formação do intermediário ativo na reação de oxidação. O mecanismo alternativo de oxidação envolve a participação de radicais.
\end{abstract}

A poly-halogenated iron porphyrin, $\mathrm{Fe}\left(\mathrm{PCl}_{8}\right) \mathrm{Cl}$, has been synthesised and used as a catalyst in hydrocarbon oxidations by iodosylbenzene and hydrogen peroxide both in solution and covalently bound to aminopropylated silica. The poly-chlorinated iron porphyrin shows the same efficiency of the related $\mathrm{Fe}(\mathrm{P}) \mathrm{Cl}$, in the epoxidation of alkenes but higher efficiency in the hydroxylation of alkanes by iodosylbenzene, with increased preference for the oxidation of secondary carbon in adamantane and primary carbon in the oxidation of pentane. These selectivities may reflect the steric constraints around the oxo-iron species or, alternatively, it may arise from the greater reactivity of the active oxidant from $\mathrm{Fe}\left(\mathrm{PCl}_{8}\right) \mathrm{Cl}$. The supported iron(III) porphyrin showed lower activity as compared with the homogeneous analogue and the related supported $\mathrm{Fe}(\mathrm{P}) \mathrm{Cl}$. The poly-chlorinated iron porpyrin is a poor catalyst with hydrogen peroxide. Excessive substitutuion by electron withdrawing groups on the porphyrin periphery eventually prohibits the formation of the key intermediate in catalytic oxidations. The alternative oxidation mechanism could involve radical participation.

Keywords: poly-halogenated iron porphyrins, catalysis, supported catalysts, hydrocarbon oxidation

\section{Introduction}

About 25 years have passed since an iron(III) porphyrin, [iron(III) tetraphenylporphyrin] with iodosylbenzene was first used as a functional model for cytochrome P-450 for hydrocarbon oxidation. ${ }^{1}$ The success of this pioneering work led to the synthesis of other metallo tetraarylporphyrins

* e-mail: mddassis@usp.br and the development of three generations of catalysts, which differ depending on the degree of substitution on the porphyrin ring. ${ }^{2}$ Although the syntheses of the second and third generation porphyrins involve more expensive starting materials and are more time consuming, their improved robustness towards oxidative degradation and greater catalytic efficiency has led to detailed studies on oxidations catalyzed by these complexes. ${ }^{2-5} \mathrm{~A}$ further approach to 
improve these systems has involved anchoring the complexes onto solid supports with the aim of allowing catalyst recovery and reuse. In this way, immobilization of the catalyst might provide a way to reduce the overall cost of using these compounds in synthesis. ${ }^{6,7}$

One aspect of our studies has been to develop robust metallo porphyrins for use with the clean oxidant hydrogen peroxide and, in particular, to use porphyrin ligands that can be readily attached to solid supports. This has led us to synthesize metallo tetraarylporphyrins containing one pentafluorophenyl group. The latter group is susceptible to nucleophilic substitution in the para-position, enabling immobilization by covalent binding to an aminofunctionalized support. ${ }^{8}$

In this paper we report the catalytic results obtained with iron(III) 5-(pentafluorophenyl)-10,15,20-tris(2,6dichlorophenyl)-2,3,7,8,12,13,17,18-octachloroporphyrin, $\mathrm{Fe}\left(\mathrm{PCl}_{8}\right) \mathrm{Cl}$ (Figure 1), in alkene and alkane oxidation by iodosylbenzene and hydrogen peroxide, both in homogeneous solution and when anchored onto aminopropylsilica and compare these results with those obtained with the analogue iron(III) 5-(pentafluorophenyl)10,15,20-tris(2,6-dichlorophenyl)porphyrin, $\mathrm{Fe}(\mathrm{P}) \mathrm{Cl}$ (Figure 1). The $\mathrm{Fe}\left(\mathrm{PCl}_{8}\right) \mathrm{Cl}$ catalyst has been synthesized by the method reported for the manganese analogue, ${ }^{8}$ and characterized by UV/Vis and electron paramagnetic resonance (EPR) spectroscopy. The interactions of $\mathrm{Fe}\left(\mathrm{PCl}_{8}\right) \mathrm{Cl}$ and the related $\mathrm{Fe}(\mathrm{P}) \mathrm{Cl}$ (Figure 1), with imidazole have also been investigated to help understand the effect of the extra chlorine atoms on $\beta$-pyrrole carbons on the reactivity of the former catalyst.

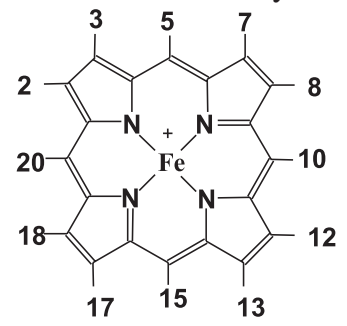

\begin{tabular}{ll}
$\mathrm{Fe}(\mathrm{P}) \mathrm{Cl}$ & $\begin{array}{l}\text { Iron(III) 5-(pentafluorophenyl)-10,15,20-tris(2,6-dichlorophenyl)- } \\
\text { porphyrin }\end{array}$ \\
\hline $\mathrm{Fe}\left(\mathrm{PCl}_{8}\right) \mathrm{Cl}$ & $\begin{array}{l}\text { Iron(III) 5-(pentafluorophenyl)-10,15,20-tris(2,6-dichlorophenyl)- } \\
2,3,7,8,12,13,17,18 \text {-octachloroporphyrin }\end{array}$
\end{tabular}

Figure 1. Iron(III) porphyrin catalysts.

\section{Experimental}

\section{Instrumental methods}

GC analyses were performed with two systems using nitrogen as the carrier gas: (i)a Varian Star 3400CX chromatograph with a flame ionization detector using a DB-wax (1 mm film thickness) megabore column (30 m, i.d. $0.54 \mathrm{~mm}$ ) and the results were analyzed on a Varian Workstation and (ii) a Hewlett Packard HP 6890 Series GC System, coupled to a flame ionization detector, using a capillary column [HP-INNOWAX, cross-linked poly(ethylene glycol), $30 \mathrm{~m}$; i.d. $0.25 \mathrm{~mm}$, film thickness $0.25 \mu \mathrm{m}] . \mathrm{FAB}^{+}$mass spectra were obtained on a V. G. Analytical Autospec spectrometer using 4-nitrobenzyl alcohol as the matrix. UV-Vis spectra were obtained with a Hewlett-Packard 8452A diode array spectrometer. In the case of supported catalysts the spectra were recorded in a 2 $\mathrm{mm}$ path length quartz cell, using a mixture of the supported iron porphyrin and the support in a suspension in $\mathrm{CCl}_{4}$. EPR spectra were recorded with a Varian E-109 spectrometer, operating in the $\mathrm{X}$ band frequency $(9 \mathrm{GHz})$ with a gain of $10^{3}$ and $20 \mathrm{~mW}$ of microwave power and amplitude modulation of 4 gauss at liquid helium temperature.

\section{Materials}

Unless otherwise specified all compounds used were purchased from Aldrich, Merck or Reagen and were analytical grade. Methanol was refluxed over a magnesium and iodine mixture and after distillation stored over $4 \AA$ molecular sieves. Iodosylbenzene was prepared in two steps from iodobenzene following the method described by Saltzmann and Sharefkin ${ }^{9}$ and the purity was shown to be $97 \%$, determined by iodometric titration. The alkene (Z-cyclooctene) was purified by passing it through a short activated alumina column (Merck) immediately before use. Aminopropyl modified silica with $9 \%$ functionalization was purchased from Aldrich and used without further treatment. Silica gel used for column chromatography was Kiesegel 60 Merck (230-400 mesh). TLC used aluminium backed silica gel $60 \mathrm{~F}_{254}$ plates (Merck). The $\mathrm{H}_{2}(\mathrm{P}), \mathrm{Zn}(\mathrm{P})$ and $\mathrm{Fe}(\mathrm{P}) \mathrm{Cl}$ used in this study were synthesized previously. ${ }^{8}$

Synthesis of iron(III) 5-(pentafluorophenyl)-10,15,20tris(2,6-dichlorophenyl)-2,3, 7, 8, 12,13,17,18octachloroporphyrin, $\mathrm{Fe}\left(\mathrm{PCl}_{8}\right) \mathrm{Cl}$

The free base 5-(pentafluorophenyl)-10,15,20-tris(2,6dichlorophenyl)-2,3,7,8,12,13,17,18-octachloroporphyrin, $\mathrm{H}_{2}\left(\mathrm{PCl}_{8}\right)$, was prepared by chlorination of zinc 5-(pentafluorophenyl)-10,15,20-tris(2,6-dichlorophenyl)porphyrin, $\mathrm{Zn}(\mathrm{P})$ (42.5 mg), with $\mathrm{N}$-chlorosuccinimide $(58.5 \mathrm{mg})$ followed by demetallation with trifluoroacetic acid, as described previously. ${ }^{8} \mathrm{H}_{2}\left(\mathrm{PCl}_{8}\right)$ was 
purified by chromatography on a silica column with hexane:dichloromethane (3:1) as eluent to give $40.3 \mathrm{mg}$ (3.4 $\times 10^{-5} \mathrm{~mol}, 78 \%$ yield) of $\mathrm{H}_{2}\left(\mathrm{PCl}_{8}\right)$. UV-Visible $\left(\mathrm{CH}_{2} \mathrm{Cl}_{2}\right): \lambda \mathrm{n}_{\mathrm{nm}}\left(\varepsilon=x 10^{2} \mathrm{~L} \mathrm{~mol}^{-1} \mathrm{~cm}^{-1}\right): 444(210), 542(22)$, 628(4), 692(1). $\mathrm{m} / \mathrm{z}\left(\mathrm{FAB}^{+}\right): 1186.654(100 \%$ - relative abundance), corresponding to $\mathrm{C}_{44} \mathrm{H}_{11} \mathrm{~N}_{4} \mathrm{~F}_{5}{ }^{35} \mathrm{Cl}_{11}{ }^{37} \mathrm{Cl}_{3}$.

Iron porphyrin, $\mathrm{Fe}\left(\mathrm{PCl}_{8}\right) \mathrm{Cl}$, was obtained by metallation of the free ligand $\mathrm{H}_{2}\left(\mathrm{PCl}_{8}\right) 40.3 \mathrm{mg}\left(3.4 \times 10^{-5} \mathrm{~mol}\right)$ with iron(II) chloride dihydrate $\left(55.3 \mathrm{mg} 3.4 \times 10^{-4} \mathrm{~mol}\right)$ in acetonitrile $(25 \mathrm{~mL})$ following the method described by Kadish et al. ${ }^{10}$ At the end of the reaction the solvent was removed under vacuum and the resulting iron porphyrin was purified by chromatography on a silica column. Elution with dichloromethane gave a small amount of free base porphyrin and methanol:dichloromethane (1:1) mixture gave the desired compound. Hydrogen chloride was bubbled through the solution to ensure that chloride was the axial ligand. TLC analysis on silica using methanol:dichloromethane as eluent confirmed the presence of $\mathrm{Fe}\left(\mathrm{PCl}_{8}\right) \mathrm{Cl}$ as the only product. The solution was evaporated to dryness and $39.7 \mathrm{mg}\left(3.2 \times 10^{-5} \mathrm{~mol}\right)$ of $\mathrm{Fe}\left(\mathrm{PCl}_{8}\right) \mathrm{Cl}$ were obtained (94\% yield). UV-Visible $\left(\mathrm{CH}_{2} \mathrm{Cl}_{2}\right), \mathrm{Fe}\left(\mathrm{PCl}_{8}\right) \mathrm{Cl}: \lambda_{\mathrm{nm}}\left(\varepsilon=\mathrm{x} 10^{2} \mathrm{~L} \mathrm{~mol}^{-1} \mathrm{~cm}^{-1}\right): 394$ (854); 440 (933). $\mathrm{m} / \mathrm{z}\left(\mathrm{FAB}^{+}\right): 1239.566(100 \%$ - relative abundance) corresponding to $\mathrm{FeC}_{44} \mathrm{H}_{9} \mathrm{~N}_{4} \mathrm{~F}_{5}{ }^{35} \mathrm{Cl}_{11}{ }^{37} \mathrm{Cl}_{3}$.

\section{Synthesis of supported catalyst}

The supported catalyst was prepared through reaction of $\mathrm{Fe}\left(\mathrm{PCl}_{8}\right) \mathrm{Cl}(0.184 \mathrm{mmol})$ with aminopropylated-silica $\left(500 \mathrm{mg}\right.$ ) in diglyme at $140^{\circ} \mathrm{C}$ under argon for $6 \mathrm{~h}$, following the method described of Mansuy et al. ${ }^{4,11}$ The resulting solid was filtered and extracted with $\mathrm{CH}_{2} \mathrm{Cl}_{2}(24 \mathrm{~h})$ and then $\mathrm{CH}_{3} \mathrm{OH}(24 \mathrm{~h})$ by a Soxhlet procedure. The solid was then dried at $80{ }^{\circ} \mathrm{C}$ for $24 \mathrm{~h}$. The iron porphyrin loading was obtained by elemental analysis (CNH) as $0.348 \mu \mathrm{mol}$ per $\mathrm{g}$ of silica. Soret band at $420 \mathrm{~nm}$.

\section{Alkene and alkane oxidations}

Iodosylbenzene. Reactions were performed in air at room temperature in small conical vessels $(3 \mathrm{~mL})$ with magnetic stirring. The iron porphyrin or supported iron porphyrin $(0.25 \mu \mathrm{mol})$ was stirred with the desired substrate $(500 \mu \mathrm{mol})$ in dichloromethane $(1.5 \mathrm{~mL})$ before the oxidant ( $25 \mu \mathrm{mol})$ was added. For reactions in the presence of cocatalyst (imidazole) the heterocyclic base was added as a solution in dichloromethane (see Table 7 for concentrations). The formation of reaction products was monitored by removing aliquots $(0.5 \mu \mathrm{L})$ for $\mathrm{GC}$ analysis. For some reactions the molar ratio of porphyrin $(0.25$ $\mu$ mol):oxidant:substrate was 1:25:6000. In order to evaluate the catalyst stability it was reused with five new charges ( $80 \mu \mathrm{mol}$ each) of PhIO added at $2 \mathrm{~h}$ intervals. The yields following each of the five consecutive additions were calculated from the total amount of oxidant used. For the supported catalyst, recycling was carried out after the fourth cycle of repeated iodosylbenzene addition by recovering the solid by filtration, washed with methanol, dried and reused it in a new reaction.

Hydrogen peroxide. The reactions were performed in a similar way to those described above. Iron porphyrin and co-catalyst were stirred in a dichloromethane : acetonitrile $(1: 1)$ solvent mixture. The substrate was then added and followed, a few minutes later, by hydrogen peroxide (30\% $\mathrm{m} / \mathrm{v}$ ) using a micro syringe. The reaction was monitored by $\mathrm{GC}$ analysis. In the best conditions, the hydrogen peroxide was added in small portions $(50 \mu \mathrm{L})$ from a stock solution $\left[0.125 \mathrm{~mol} \mathrm{~L}^{-1}\right.$ in dichloromethane:acetonitrile (1:1)] at 20 min intervals until the total amount of oxidant used reached $25 \mu \mathrm{mol}$.

The $\mathrm{H}_{2} \mathrm{O}_{2}$ content after reactions was analysed by titration with a standard solution of potassium permanganate $3.75 \times 10^{-2} \mathrm{~mol} \mathrm{~L}^{-1}$.

\section{Titration of $\mathrm{Fe}\left(\mathrm{PCl}_{8}\right) \mathrm{Cl}$ and $\mathrm{Fe}(\mathrm{P}) \mathrm{Cl}$ with imidazole}

Titrations of $\mathrm{Fe}\left(\mathrm{PCl}_{8}\right) \mathrm{Cl}$ and $\mathrm{Fe}(\mathrm{P}) \mathrm{Cl}$ with imidazole were carried out with iron porphyrin solutions in $0.2 \mathrm{~mm}$ path length cells at $24{ }^{\circ} \mathrm{C}$. The reaction was monitored by following visible spectral changes of $\sim 22.5 \mu \mathrm{mol} \mathrm{L}^{-1}$ solutions $\left(\mathrm{CH}_{2} \mathrm{Cl}_{2}\right)$ of iron porphyrin upon addition of aliquots of ligand stock solution $\left(0.17 \mathrm{~mol} \mathrm{~L}^{-1}\right)$ up to constant absorbance at $560 \mathrm{~nm}$ or $550 \mathrm{~nm}$ for $\mathrm{Fe}\left(\mathrm{PCl}_{8}\right) \mathrm{Cl}$ and $\mathrm{Fe}(\mathrm{P}) \mathrm{Cl}$, respectively. The equilibrium constant $\left(\beta_{\mathrm{n}}\right)$ and the axial ligand number (n) were calculated from the equation of Fleisher and Fine, ${ }^{12}$ using absorbance data from $\lambda=560$ or $550 \mathrm{~nm}$ :

$\log \left[\left(\mathrm{A}-\mathrm{A}_{0}\right) /\left(\mathrm{A}_{\mathrm{oo}}-\mathrm{A}\right)\right]=\mathrm{n} \log [\mathrm{L}]_{\mathrm{ad}}+\log \beta_{\mathrm{n}}$

where $\mathrm{A}_{0}$ is the absorbance of the initial iron porphyrin solution, $\mathrm{A}$ is the absorbance of the solution containing some concentration of the ligand and $\mathrm{A}_{\mathrm{oo}}$ the absorbance of the solution containing iron porphyrin totally coordinated to the ligand.

This equation can be used under conditions where $\beta_{\mathrm{n}}$ $\leq 10^{5}$, since little ligand reacts with the iron porphyrin, and the amount of ligand added $\left(\mathrm{L}_{\mathrm{ad}}\right)$ effectively equals the concentrations of the ligand in the equilibrium (L). ${ }^{13-16}$ By plotting $\log \left[\left(\mathrm{A}-\mathrm{A}_{\mathrm{o}}\right) /\left(\mathrm{A}_{\mathrm{oo}}-\mathrm{A}\right)\right]$ versus $\log \left[\mathrm{L}_{\text {ad }}\right]$ the $\mathrm{n}$ and $\beta_{n}$ values are obtained. In the case of $\beta_{n} \geq 10^{5}$, there is 
a large iron porphyrin-ligand interaction and thus almost all the ligand added to the system reacts with the iron porphyrin. Therefore $[\mathrm{L}]$ differs considerably from $\left[\mathrm{L}_{\mathrm{ad}}\right]$, and the plot $\log \left[\left(\mathrm{A}-\mathrm{A}_{\mathrm{o}}\right) /\left(\mathrm{A}_{\mathrm{oo}}-\mathrm{A}\right)\right]$ versus $\log \left[\mathrm{L}_{\mathrm{ad}}\right]$, has to be replaced by the plot of $\log \left[\left(\mathrm{A}_{-} \mathrm{A}_{\mathrm{o}}\right) /\left(\mathrm{A}_{\mathrm{oo}}-\mathrm{A}\right)\right]$ versus $\log [\mathrm{L}]$. [L] can be calculated by following equation: ${ }^{16,17}$

$[\mathrm{L}]=\left[\mathrm{L}_{\mathrm{ad}}\right]-[\mathrm{FeP}]\left[\left(\mathrm{A}-\mathrm{A}_{\mathrm{o}}\right) /\left(\mathrm{A}_{\mathrm{oo}}-\mathrm{A}\right)\right]$

\section{Results and Discussion}

Synthesis and characterization of homogeneous, $\mathrm{Fe}\left(\mathrm{PCl}_{8}\right) \mathrm{Cl}$, and heterogeneous, $\mathrm{Si}-\mathrm{Fe}\left(\mathrm{PCl}_{8}\right) \mathrm{Cl}$, catalysts

The iron porphyrin $\mathrm{Fe}\left(\mathrm{PCl}_{8}\right) \mathrm{Cl}$ was synthesized following the method reported previously for the manganese analogue ${ }^{8}$ and UV/Vis spectrocopy shows a Soret band at $440 \mathrm{~nm}$. This is, as expected, red shifted when compared to the value for $\mathrm{Fe}(\mathrm{P}) \mathrm{Cl}(416 \mathrm{~nm})$ due to the eight electronegative chlorine atoms on the $\beta$-pyrrole carbons. ${ }^{18,19}$

The iron porphyrin was immobilized onto aminopropylated silica to give a catalyst loading of 0.348 mmol g-1 of support. Normally, the iron porphyrins bearing pentafluorophenyl substituents are grafted by nucleophilic aromatic substitution of a para-fluorine., ${ }^{411}$ However, in this case one or more chlorine atoms on the b-pyrrole carbon could also be substituted leading to a catalyst imobilized through the pyrrole of the porphyrin ring, resulting in a strained macrocycle on the support. This could explain the blue shifted Soret band (420 nm) of $\mathrm{Si}-\mathrm{Fe}\left(\mathrm{PCl}_{8}\right) \mathrm{Cl}$ compared to the iron(III) porphyrin in dichloromethane (444 nm). Also the EPR spectrum of the solid catalyst indicates a distorted porphyrin macrocycle around the iron centre (Figure 2b). The EPR spectra confirm the presence of the iron(III) in both homogeneous and supported systems, through the characteristic signals of this species (Figure $2 \mathrm{a}$ and $2 \mathrm{~b}$ ). However, the $\mathrm{g}$ values and the morphology of the spectrum of homogeneous $\mathrm{Fe}\left(\mathrm{PCl}_{8}\right) \mathrm{Cl}$ differ from those of the supported metallo porphyrin, reflecting the different symmetries of these two iron centers. In solution the iron is a high spin $5 / 2$ system, with a $g_{\wedge}$ value of 5.635 and $g_{\|}$of 2.000 (Figure $2 \mathrm{a})$. When the iron porphyrin is attached to the support, the EPR spectrum shows a more intense and asymmetric signal at $\mathrm{g}=4.3$ attributed to a rhombic iron porphyrin structure (Figure 2b). This signal and a rhombic symmetry of the iron d orbitals has been found for other distorted species having an oxo or nitrene metal-pyrrole nitrogen bond, (P)Fe-X-N ( $\mathrm{X}$ is $\mathrm{O}$ or $\mathrm{N}$ ) reported by Mansuy et al. ${ }^{20-22}$ and Groves and Watanabe. ${ }^{23}$ The catalytic results also
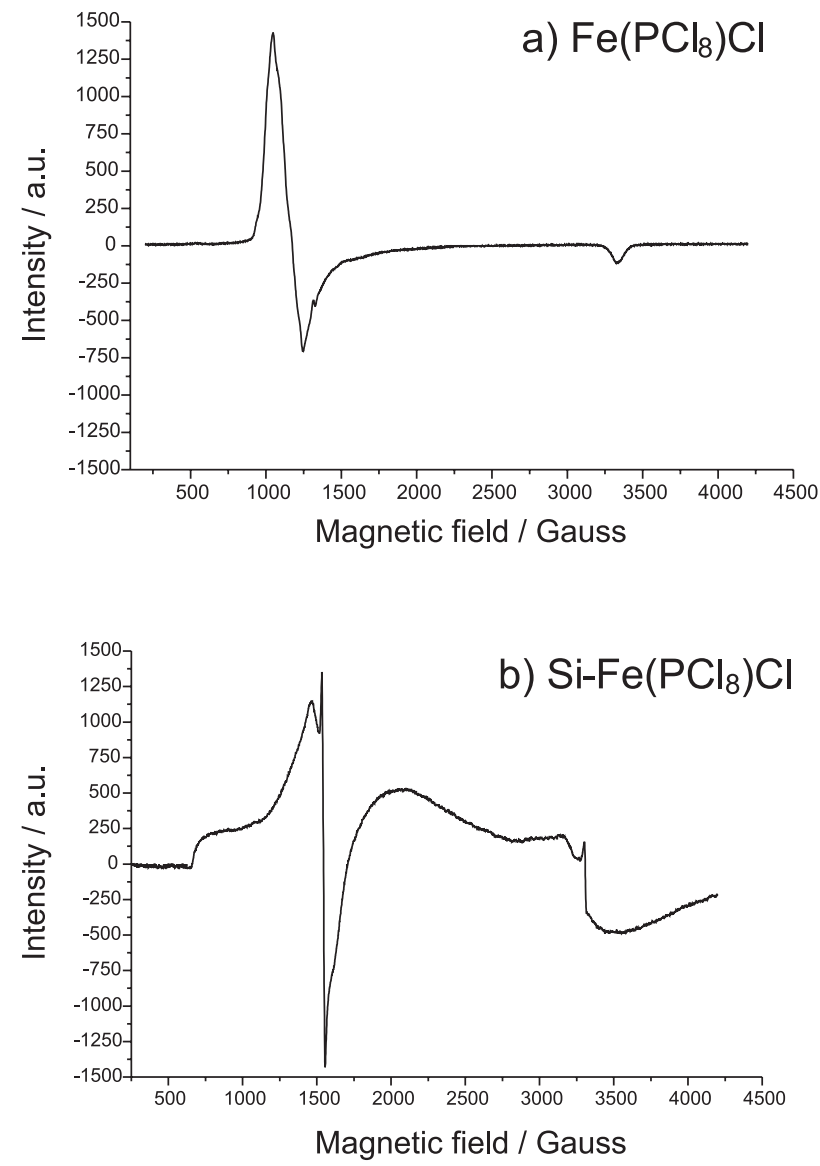

Figure 2. EPR spectra of $\mathrm{Fe}^{\mathrm{III}}\left(\mathrm{PCl}_{8}\right) \mathrm{Cl}$ in dichloromethane solution (a) and supported on aminopropylated silica (b). Both spectra were recorded at $4 \mathrm{~K}$ and gain $10^{3}, 20 \mathrm{~mW}$ microwave power at $9.12 \mathrm{GHz}$ and $10 \mathrm{G}$ modulation.

reflect the high constraint around the iron center of anchored $\mathrm{Fe}\left(\mathrm{PCl}_{8}\right) \mathrm{Cl}$.

With the aim of understanding the accessibility of the iron centre, the coordination of $\mathrm{Fe}^{\mathrm{III}}\left(\mathrm{PCl}_{8}\right) \mathrm{Cl}$ with axial ligands was investigated through spectrophotometric titration with imidazole. The parent iron porphyrin, $\mathrm{Fe}(\mathrm{P}) \mathrm{Cl}$, was also studied for comparison to help evaluate the steric and electronic effects of $\beta$ - chlorine substituents on the axial ligand coordination.

The Figures 3 and 4 show the changes in UV/Vis spectra during titration of both iron porphyrins and Table 1 shows the number of ligands (n) and the equilibrium

Table 1. Values for the number of coordinated Im ligand (n) and stability constants $\left(\beta_{\mathrm{n}}\right)$ for $\mathrm{Fe}(\mathrm{P}) \mathrm{Im}$ complexes

\begin{tabular}{lccc}
\hline Iron porphyrin & $\mathrm{n}$ & $\beta_{\mathrm{n}}\left(\mathrm{mol}^{-2} \mathrm{~L}^{2}\right)$ & Reference \\
\hline $\mathrm{Fe}(\mathrm{TPPCl}) \mathrm{Im}_{2}$ & 2 & $4.8 \times 10^{5}$ & 27 \\
$\mathrm{Fe}(\mathrm{TDCPP}) \mathrm{Im}_{2}$ & 2 & $8.1 \times 10^{8}$ & 28 \\
$\mathrm{Fe}(\mathrm{P}) \mathrm{Im}_{2}$ & 2 & $2.74 \times 10^{6}$ & this work \\
$\mathrm{Fe}\left(\mathrm{PCl}_{8}\right) \mathrm{Im}$ & 1 & $1.72 \times 10^{3 *}$ & this work
\end{tabular}

* Units $\mathrm{mol}^{-1} \mathrm{~L}$. 


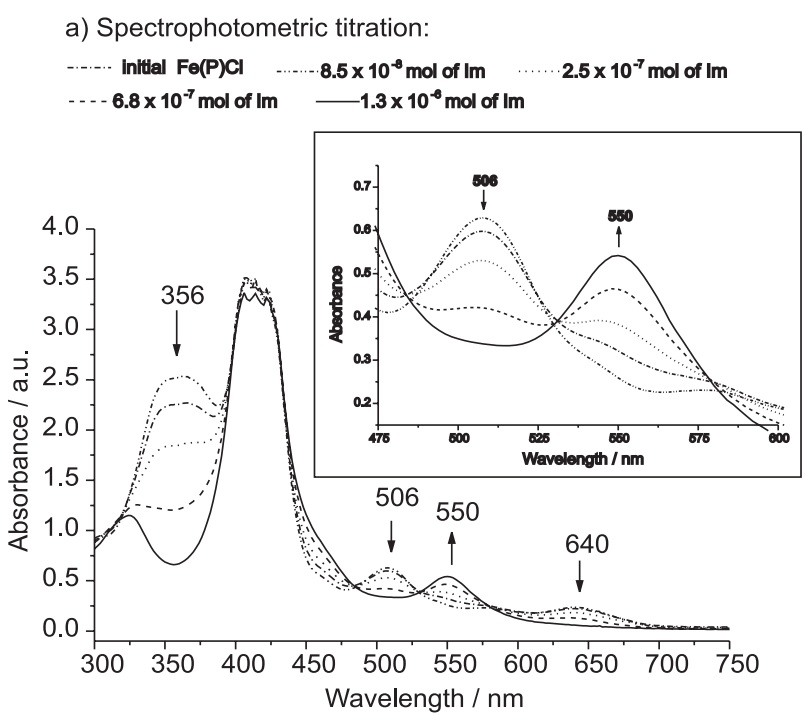

b) Plot of $\log \left(A-A_{0}\right) /\left(A_{\infty}-A\right) v s . \log [L]_{\text {ad }}(\lambda=550 \mathrm{~nm})$

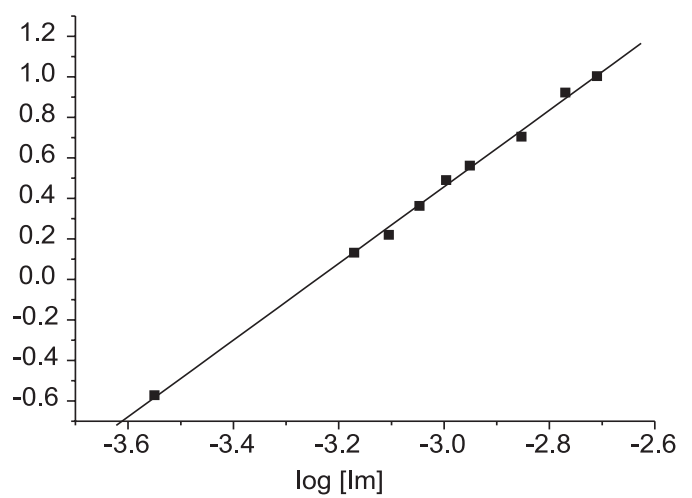

Figure 3. (a) Spectrophotometric titration of $\mathrm{Fe}(\mathrm{P}) \mathrm{Cl}$ in $\mathrm{CH}_{2} \mathrm{Cl}_{2}$ (700 $\left.\mathrm{mL}, 3.57 \times 10^{-4} \mathrm{~mol} \mathrm{~L}^{-1}, 2.5 \times 10^{-7} \mathrm{~mol}\right)$ with imidazole $(0.17 \mathrm{~mol}$ $\left.\mathrm{L}^{-1}, \mathrm{CH}_{2} \mathrm{Cl}_{2}\right)$; (b) Plot of $\left.\log (\mathrm{A}-\mathrm{Ao}) / \mathrm{A}_{\infty}-\mathrm{A}\right) v s \cdot \log [\mathrm{L}](\lambda=550 \mathrm{~nm})$ used to calculate the number of coordinated $\operatorname{Im}(\mathrm{n})$ and stability constant $\left(\beta_{\mathrm{n}}\right)$ for $\mathrm{Fe}(\mathrm{P})(\mathrm{Im})_{\mathrm{n}}$ complexes.

constants $\left(\beta_{\mathrm{n}}\right)$ for both iron porphyrins. It can be observed that the addition of imidazole to a solution of $\mathrm{Fe}(\mathrm{P}) \mathrm{Cl}$ results in a decrease in the absorption at 506 and $640 \mathrm{~nm}$ and a simultaneous increase in the absorption at $550 \mathrm{~nm}$ (Figure 3a), due to the chlorine/imidazole ligands exchange with isosbestic points at 495, 525 and $590 \mathrm{~nm}$ (Figure 3). The overall equilibrium constant was determined as described in the experimental using the equation for $\beta_{\mathrm{n}} \geq 10^{5}$. It is observed in Table 1 that $\mathrm{Fe}(\mathrm{P}) \mathrm{Cl}$ is able to coordinate with two imidazole ligands with overall equilibrium constant of $2.74 \times 10^{6} \mathrm{~mol}^{-2} \mathrm{~L}^{2}$ which is higher than $\mathrm{Fe}(\mathrm{TPP}) \mathrm{Cl}(\mathrm{TPP}=5,10,15,20$ tetraphenylporphyrin) in the same solvent, ${ }^{23,25}$ but lower than $\mathrm{Fe}$ (TDCPP)Cl (TDCPP $=5,10,15,20$-tetrakis $(2,6-$ dichlorophenyl)porphyrin) in dichloroethane, as determined by Serra et al. $^{26}$

The addition of imidazole to a solution of $\mathrm{Fe}\left(\mathrm{PCl}_{8}\right) \mathrm{Cl}$ results in different spectral changes as shown in Figure 4a.

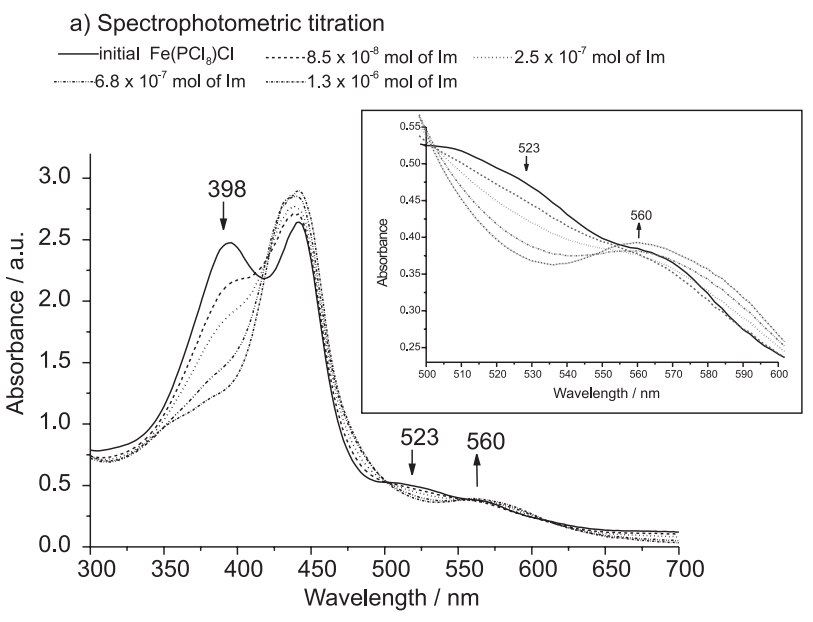

b) Plot of $\log \left(A-A_{0}\right) /\left(A_{\infty}-A\right) v s . \log [L]_{a d}(\lambda=560 n m)$

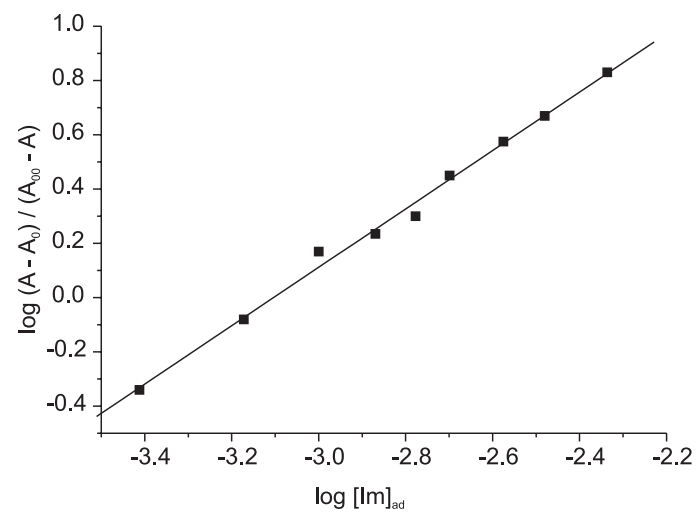

Figure 4. (a) Spectrophotometric titration of $\mathrm{Fe}\left(\mathrm{PCl}_{8}\right) \mathrm{Cl}$ in $\mathrm{CH}_{2} \mathrm{Cl}_{2}$ $\left(700 \mathrm{~mL}, 3.57 \times 10^{-4} \mathrm{~mol} \mathrm{~L}^{-1}, 2.5 \times 10^{-7} \mathrm{~mol}\right)$ with imidazole $(0.17$ mol L $\left.{ }^{-1}, \mathrm{CH}_{2} \mathrm{Cl}_{2}\right)$; (b) Plot of $\left.\log \left(\mathrm{A}-\mathrm{A}_{\mathrm{o}}\right) / \mathrm{A}_{\infty}-\mathrm{A}\right) v s . \log [\mathrm{L}]_{\mathrm{ad}}(\lambda=560$ $\mathrm{nm}$ ) used to calculate the number of coordinated $\operatorname{Im}(\mathrm{n})$ and stability constants $\left(\beta_{\mathrm{n}}\right)$ for $\mathrm{Fe}\left(\mathrm{PCl}_{8}\right)(\mathrm{Im})_{\mathrm{n}}$ complexes.

There is a decrease in the absorption at $523 \mathrm{~nm}$ and a simultaneous increase in the absorption at $560 \mathrm{~nm}$ with isosbestic points at 502, 555 and $618 \mathrm{~nm}$. Only one imidazole ligand binds to the metal centre in $\mathrm{Fe}\left(\mathrm{PCl}_{8}\right)^{+}$ as estimated from the plot of Figure $4 \mathrm{~b}$ and the equilibrium constant $\left(\beta_{1}\right)$ was estimated as $1.72 \times 10^{3}$ mol $^{-1} \mathrm{~L}$ (Table 1).

It was expected that, if steric effects are absent, the more electron deficient porphyrin ring might give the metal a higher affinity for axial ligands as observed by Serra et al. ${ }^{26}$ and Hatano et al. ${ }^{27}$ However, in the case of $\mathrm{Fe}\left(\mathrm{PCl}_{8}\right) \mathrm{Cl}$ the extra steric hindrance and the distortion of the porphyrin ring provoked by the $\beta$-chlorine atoms dominates the electron-withdrawing effect of these substituents and prevents the binding of the second ligand to the metal, in the same way as observed by Balch et al for $\mathrm{Fe}$ (TMP) (TMP = 5,10,15,20-tetramesitylporphyrin) which coordinates with only one $\mathrm{OH}^{-}$ion. ${ }^{28}$ 
Alkene and alkane oxidations by iodosylbenzene catalysed by $\mathrm{Fe}\left(\mathrm{PCl}_{8}\right) \mathrm{Cl}$ in homogeneous solution and anchored to aminopropylated silica

The catalytic activity of $\mathrm{Fe}\left(\mathrm{PCl}_{8}\right) \mathrm{Cl}$ for hydrocarbon oxidation in homogeneous solution was examined with cyclooctene, cyclohexane, adamantane and pentane (Tables 2 and 3) to evaluate the selectivity and accessibility of the iron centre in this robust catalyst compared to the related second generation iron porphyrin, $\mathrm{Fe}(\mathrm{P}) \mathrm{Cl}$.

The reactions were carried out under two conditions: (i) FeP : PhIO : substrate ratio of 1 : 100 : 2000 which are defined as the standard conditions in our laboratory and allows comparison with many other iron porphyrin systems and (ii) FeP : PhIO : substrate ratio of $1: 25: 6000$, which are optimized conditions since the lower oxidant and higher substrate relative concentrations favors substrate oxidation over unwanted competitive reactions.

For cyclooctene and cyclohexane oxidations, the results from Table 2, do not show an improvement over $\mathrm{Fe}(\mathrm{P}) \mathrm{Cl}$ (entries 1, 2 and 4, 5) despite the increased electrophilicity of the macrocycle due to the presence of the additional electron-withdrawing $\mathrm{Cl}$ groups. A similar result was also obtained for the analogous manganese porphyrin system. ${ }^{8}$ These results are probably related to the structure of the reactive intermediate to which the porphyrin has to be oxidized during catalysis. Excessive substitution by electron-withdrawing groups on the porphyrin periphery may prohibit the formation of the key oxoiron(IV) porphyrin $\pi$-cation radical, $\mathrm{O}=\mathrm{Fe}^{\mathrm{IV}} \mathrm{P}^{+}$, as reported by Gross and Simkhovich for similar second and third iron porphyrins. ${ }^{5}$ Mansuy et al. ${ }^{31}$ observed that with very electron-deficient porphyrins, $\mathrm{O}=\mathrm{Fe}^{\mathrm{IV}} \mathrm{P}^{+}$. is not favoured as the $\pi$-cation radical cannot be stabilised by the porphyrin ring and the active oxidant behaves more as a radical species, $\cdot \mathrm{O}-\mathrm{Fe}^{\mathrm{IV}+} \mathrm{P}$.

The best catalytic results were obtained in optimised conditions (Table 2, entries 3 and 6) since the lower oxidant and higher substrate relative concentrations favour substrate oxidation over unwanted competitive reactions.

In contrast to cyclooctene and cyclohexane, for adamantane, the catalytic activity of $\mathrm{Fe}\left(\mathrm{PCl}_{8}\right) \mathrm{Cl}$ was higher than that for $\mathrm{Fe}(\mathrm{P}) \mathrm{Cl}$ (Table 3 - entries 1 and 2). In the adamantane oxidation, the robust iron porphyrin $\mathrm{Fe}\left(\mathrm{PCl}_{8}\right) \mathrm{Cl}$ shows a higher preference for 2-position $\left(\mathrm{C}^{\mathrm{sec}}\right)$ over 1-position $\left(\mathrm{C}^{\text {tert }}\right)$ compared to $\mathrm{Fe}(\mathrm{P}) \mathrm{Cl}$, with statistically corrected selectivity $\mathrm{C}^{\mathrm{tert}} / \mathrm{C}^{\mathrm{sec}}$ of 4 and 14 respectively for both iron porphyrins. This difference in selectivity may reflect the difference in steric constraints around the oxoiron species. Alternatively it may arise from the greater reactivity of the active oxidant from $\mathrm{Fe}\left(\mathrm{PCl}_{8}\right) \mathrm{Cl}$ which results in an earlier transition state in the oxidation step.

Table 2. Cyclooctene and cyclohexane oxidations by $\mathrm{PhIO}$ catalysed by $\mathrm{Fe}\left(\mathrm{PCl}_{8}\right) \mathrm{Cl}$ and $\mathrm{Fe}(\mathrm{P}) \mathrm{Cl}$

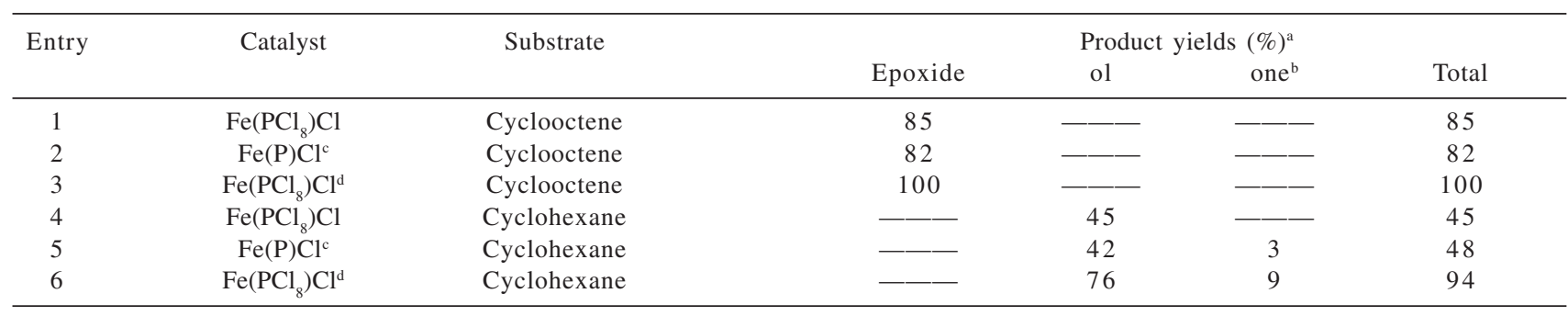

$\mathrm{Fe}\left(\mathrm{PCl}_{8} \mathrm{P}\right) \mathrm{Cl}$ and $\mathrm{Fe}(\mathrm{P}) \mathrm{Cl}(0.25 \mu \mathrm{mol})$ at $25{ }^{\circ} \mathrm{C}$; $\mathrm{FeP}: \mathrm{PhIO}:$ substrate ratio of $1: 100: 2000$; solvent : $1.5 \mathrm{~mL}$ of dichloroethane; ol $=$ cyclohexanol; one = cyclohexanone; epoxide = cyclooctenoxide; ${ }^{a}$ yields related to PhIO; ${ }^{\mathrm{b}} \mathrm{PhIO}$ conversion, ketone yields assume the consumption of two $\mathrm{PhIO} ;{ }^{\mathrm{c}}$ from ref. $29 ;{ }^{\mathrm{d}} \mathrm{Fe}\left(\mathrm{PCl}_{8} \mathrm{P}\right) \mathrm{Cl}(0.25 \mu \mathrm{mol})$ : $\mathrm{PhIO}$ : substrate (1:25: 6000).

Table 3. Adamantane and pentane oxidations by $\mathrm{PhIO}$ catalysed by $\mathrm{Fe}\left(\mathrm{PCl}_{8}\right) \mathrm{Cl}$ and $\mathrm{Fe}(\mathrm{P}) \mathrm{Cl}$

\begin{tabular}{|c|c|c|c|c|c|c|c|}
\hline \multirow[t]{2}{*}{ Entry } & \multirow[t]{2}{*}{ Catalyst } & \multirow[t]{2}{*}{ Substrate } & \multicolumn{4}{|c|}{ Product Yields $(\%)^{\mathrm{a}}$} & \multirow[b]{2}{*}{ Total } \\
\hline & & & $1-\mathrm{ol}$ & 2-ol & 3-ol & one $^{b}$ & \\
\hline 1 & $\mathrm{Fe}\left(\mathrm{PCl}_{8}\right) \mathrm{Cl}$ & Adamantane & 54 & 38 & - - & 3 & 98 \\
\hline 2 & $\mathrm{Fe}(\mathrm{P}) \mathrm{Cl}^{\mathrm{d}}$ & Adamantane & 69 & 15 & - - - & $<1$ & 84 \\
\hline 3 & $\mathrm{Fe}\left(\mathrm{PCl}_{8}\right) \mathrm{Cl}$ & Pentane & 4 & 22 & 11 & 5 & 47 \\
\hline 4 & $\mathrm{Fe}\left(\mathrm{PCl}_{8}\right) \mathrm{Cl}^{\mathrm{e}}$ & Pentane & 13 & 36 & 15 & 9 & 82 \\
\hline 5 & $\mathrm{Fe}(\mathrm{P}) \mathrm{Cl}$ & Pentane & $<1$ & 20 & 12 & $<1$ & 32 \\
\hline 6 & $\mathrm{Fe}(\mathrm{P}) \mathrm{Cl}^{\mathrm{e}}$ & Pentane & 2 & 28 & 15 & 4 & 53 \\
\hline
\end{tabular}

$\mathrm{Fe}\left(\mathrm{PCl}_{8}\right) \mathrm{Cl}$ and $\mathrm{Fe}(\mathrm{P}) \mathrm{Cl}(0.25 \mu \mathrm{mol})$ at $25{ }^{\circ} \mathrm{C} ; \mathrm{FeP}: \mathrm{PhIO}:$ substrate ratio of $1: 100: 2000$; solvent : $1.5 \mathrm{~mL}$ of dichloroethane; 1-ol, 2-ol, 3-ol

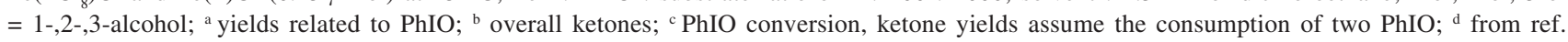
29; ${ }^{\mathrm{F} e}\left(\mathrm{PCl}_{8} \mathrm{P}\right) \mathrm{Cl}$ or $\mathrm{Fe}(\mathrm{P}) \mathrm{Cl}(0.25 \mu \mathrm{mol})$ : $\mathrm{PhIO}$ : substrate (1:25: 6000). 
Homogeneous $\mathrm{Fe}\left(\mathrm{PCl}_{8}\right) \mathrm{Cl}$ is also very effective at hydroxylating aliphatic $\mathrm{C}-\mathrm{H}$ bonds in linear alkanes such as pentane, and is better than $\mathrm{Fe}(\mathrm{P}) \mathrm{Cl}$ (Table 3 entries 3 and 4 vs. 5 and 6). The regioselectivity of pentane oxidation also reflects the steric hindrance around the catalytic centre, favouring the more accessible but less reactive position 1 . The $2-\mathrm{ol} / 3$-ol ratio is 2 in this case which is lower than that observed for $\mathrm{Fe}$ (TDCPP)Cl, a second generation catalyst (2-ol/3-ol of 3.7) and similar to that observed for the analogue $\mathrm{Fe}\left(\mathrm{TDCCl}_{8} \mathrm{PP}\right) \mathrm{Cl}\left[\mathrm{TDCCl}_{8} \mathrm{PP}\right.$ $=5,10,15,20$-tetrakis(2,6-dichlorophenyl)-2,3,7,8,12, 13,17,18-octachloroporphyrin] (2-ol/3-ol of 2.1) reported by Mansuy et al. ${ }^{30}$

These authors explained the selectivity of the oxidation in terms of the active oxidant having a more radical structure as is $\cdot \mathrm{O}-\mathrm{Fe}^{\mathrm{IV}+} \mathrm{P} .{ }^{31}$

No degradation of the catalyst was observed through $\mathrm{UV} / \mathrm{Vis}$ spectroscopy, even when $\mathrm{Fe}\left(\mathrm{PCl}_{8}\right) \mathrm{Cl}$ was used in homogeneous reactions after five additions of the oxidant (each with catalyst:oxidant, 1: 320, added at $2 \mathrm{~h}$ intervals,

Table 4. Epoxidation of cyclooctene with repeated addition of $\mathrm{PhIO}$ catalysed by $\mathrm{Fe}\left(\mathrm{PCl}_{8}\right) \mathrm{Cl}$ and $\mathrm{Si}-\mathrm{Fe}\left(\mathrm{PCl}_{8}\right) \mathrm{Cl}$, in dichloromethane

\begin{tabular}{|c|c|c|}
\hline \multirow{2}{*}{$\begin{array}{l}\text { Addition } \\
\text { of } \mathrm{PhIO}\end{array}$} & \multicolumn{2}{|c|}{ Epoxide yield $(\%)^{\mathrm{a}}$} \\
\hline & (homogeneous solution) & $\left(\mathrm{Si}-\mathrm{Fe}\left(\mathrm{PCl}_{8}\right) \mathrm{Cl}\right)$ \\
\hline 1 & 85 & 30 \\
\hline 2 & 90 & 28 \\
\hline 3 & 82 & 31 \\
\hline 4 & 78 & 27 \\
\hline 5 & 79 & $27^{\mathrm{b}}$ \\
\hline
\end{tabular}

$\mathrm{Fe}\left(\mathrm{PCl}_{8}\right) \mathrm{Cl}(0.25 \mu \mathrm{mol})$; PhIO $(80 \mu \mathrm{mol}$ per addition $)$; cyclooctene (500 $\mu \mathrm{mol}) ; \mathrm{CH}_{2} \mathrm{Cl}_{2}, 1.5 \mathrm{~mL}$; ${ }^{\mathrm{a}}$ based on $\mathrm{PhIO}$; ${ }^{\mathrm{b}}$ the supported catalyst isolated from reaction 4 was washed with methanol and dried at low pressure before this reaction.
Table 4), giving a total of 1323 catalytic turnovers. This result confirmed the stability of $\mathrm{Fe}\left(\mathrm{PCl}_{8}\right) \mathrm{Cl}$.

The supported poly-halogenated iron porphyrin was less efficient as a catalyst than the homogeneous analogue and supported $\mathrm{Fe}(\mathrm{P}) \mathrm{Cl}$ (Table 5 and 6).This is probably related to the increase in steric hindrance of the catalytic site on the support that restricts the access of the oxidant and substrate to the iron center, which is already disfavoured due to the high polarity of the solid surface. The high distortion of the iron(III) porphyrin symmetry brought about by the solid support and confirmed by the EPR spectrum of this material (Figure 2b), indicates that the solid behave as another very bulky group which reduces the activity of the catalyst.

Although immobilised catalyst have lower activity compared to solution, they can be recycled giving a reproducible yield of cyclooctene epoxide (Table 4, entry 5 ), and a total turnover number of 458. Furthermore, if in future development the supported catalyst were to be used in synthesis it can be remove by filtration at the end of the reaction, thus aiding purification of products.

\section{Alkene and alkane oxidations by hydrogen peroxide catalysed by $\mathrm{Fe}\left(\mathrm{PCl}_{8}\right) \mathrm{Cl}$ in homogeneous solution and anchored to aminopropylated silica}

The biologically important oxidant hydrogen peroxide can also be used as a source of oxygen in catalytic oxidations of hydrocarbons catalysed by synthetic metallo porphyrins. This is an attractive process because hydrogen peroxide is cheap and considered to be an environmentally clean oxidant producing water and oxygen as the only byproducts. ${ }^{33,34}$ Manganese porphyrins have been reported as

Table 5. Product yields from the oxidation of hydrocarbons by PhIO catalysed by iron(III) porphyrins anchored to aminopropylated silica

\begin{tabular}{|c|c|c|c|c|c|c|}
\hline \multirow[t]{2}{*}{ Entry } & \multirow[t]{2}{*}{ Substrate } & \multicolumn{4}{|c|}{ Products Yield $(\%)^{\mathrm{a}}$} & \multirow[b]{2}{*}{ Total $^{\mathrm{b}}$} \\
\hline & & Catalyst & Epoxide & ol & one & \\
\hline 1 & Cyclooctene & $\mathrm{Si}-\mathrm{Fe}\left(\mathrm{PCl}_{8}\right)$ & 30 & - - & - - & 30 \\
\hline 2 & Cyclooctene & $\mathrm{Si}-\mathrm{Fe}(\mathrm{P}) \mathrm{Cl}^{\mathrm{c}}$ & 82 & ——— & -—— & 82 \\
\hline 3 & Cyclohexane & $\mathrm{Si}-\mathrm{Fe}\left(\mathrm{PCl}_{8}\right)$ & - — & 2 & 2 & 6 \\
\hline 4 & Cyclohexane & $\mathrm{Si}-\mathrm{Fe}(\mathrm{P}) \mathrm{Cl}^{\mathrm{c}}$ & - - & 9 & 12 & 33 \\
\hline
\end{tabular}

$\mathrm{Si}-\mathrm{Fe}\left(\mathrm{PCl}{ }_{8} \mathrm{P}\right) \mathrm{Cl}$ and $\mathrm{Si}-\mathrm{Fe}(\mathrm{P}) \mathrm{Cl}(0.25 \mu \mathrm{mol})$ at $25{ }^{\circ} \mathrm{C}$; ol = cyclohexanol; one = cyclohexanone; $1.5 \mathrm{~mL}$ of dichloroethane; a yields related to $\mathrm{PhIO}$; ${ }^{\mathrm{b}} \mathrm{PhIO}$ conversion, ketone yields assume the consumption of two PhIO; ${ }^{\mathrm{c}}$ from ref 29.

Table 6. Product yields from the oxidation of adamantane by PhIO catalysed by iron(III) porphyrins anchored to aminopropylated silica

\begin{tabular}{ccccccc}
\hline \multirow{2}{*}{ Entry } & Substrate & \multicolumn{2}{c}{ Product yields $^{\mathrm{a}}(\%)$} & Total $^{\mathrm{b}}$ & \\
& & Catalyst & $1-$ ol & $2-$ ol & 51 & 51 \\
\hline 1 & Adamantane & $\mathrm{Si}-\mathrm{Fe}\left(\mathrm{PCl}_{8}\right)$ & 29 & 12 & 5 & 79 \\
\hline
\end{tabular}

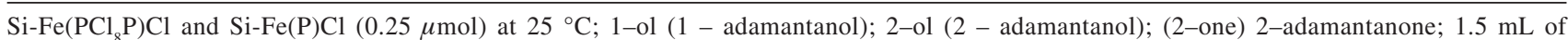
dichloroethane; ${ }^{a}$ yields related to $\mathrm{PhIO} ;{ }^{\mathrm{b}} \mathrm{PhIO}$ conversion, ketone yields assume the consumption of two PhIO; ${ }^{\mathrm{c}}$ from ref 29. 
Table 7. Oxidation of cyclooctene and cyclohexane by hydrogen peroxide catalysed by $\mathrm{Fe}\left(\mathrm{PCl}_{8}\right) \mathrm{Cl}$

\begin{tabular}{|c|c|c|c|c|c|c|}
\hline \multirow[t]{2}{*}{ Entry } & \multirow[t]{2}{*}{ Substrate } & \multirow[t]{2}{*}{ conditions } & \multicolumn{4}{|c|}{ Products yields $(\%)^{\mathrm{a}}$} \\
\hline & & & ol & one & epoxide & Tota \\
\hline 1 & cyclooctene & One aliquot of $\mathrm{H}_{2} \mathrm{O}_{2}$ & - & —- & $<1$ & $<1$ \\
\hline 2 & cyclooctene & Slow addition of 4 aliquots of $\mathrm{H}_{2} \mathrm{O}_{2}$ & -- & - - & 24 & 24 \\
\hline $3^{\mathrm{b}}$ & cyclooctene & Slow addition of 4 aliquots of $\mathrm{H}_{2} \mathrm{O}_{2} ; \mathrm{Im}$ & -- & - - & 11 & 11 \\
\hline 4 & cyclohexane & One aliquot of $\mathrm{H}_{2} \mathrm{O}_{2}$ & $<1$ & $<1$ & & $<1$ \\
\hline 5 & cyclohexane & Slow addition of 4 aliquots of $\mathrm{H}_{2} \mathrm{O}_{2}$ & $<1$ & $<1$ & & $<1$ \\
\hline $6^{\mathrm{b}}$ & cyclohexane & Slow additions in 4 aliquots of $\mathrm{H}_{2} \mathrm{O}_{2} ; \mathrm{Im}$ & 9 & 11 & & 20 \\
\hline
\end{tabular}

$\mathrm{Fe}\left(\mathrm{PCl}{ }_{8} \mathrm{P}\right) \mathrm{Cl}(0.25 \mu \mathrm{mol})$ at $25{ }^{\circ} \mathrm{C} ; 1.5 \mathrm{~mL}$ of $\mathrm{CH}_{2} \mathrm{Cl}_{2}: \mathrm{CH}_{3} \mathrm{CN}(1: 1) ; \mathrm{ol}=$ cyclohexanol; one = cyclohexanone; epoxide = cyclooctenoxide; a yields related to $\mathrm{H}_{2} \mathrm{O}_{2}$; ${ }^{\text {b }}$ ratio of catalyst : $\mathrm{H}_{2} \mathrm{O}_{2}:$ Im (imidazole) : substrate $(1: 100: 100: 2000)$.

better catalysts than iron porphyrins for these oxidations with $\mathrm{H}_{2} \mathrm{O}_{2},{ }^{2}$ due to the high catalase activity of the iron porphyrins which leads to loss of hydrogen peroxide to give water and dioxygen. ${ }^{6}$ However, Nam et al. ${ }^{35,}{ }^{36}$ have shown that electron-deficient iron porphyrins with hydrogen peroxide are capable of efficient transfer of oxygen to alkenes and alkanes to give oxygenated products. The precise nature of the active species in these systems which appears to be depended on the substituents and axial ligand of the iron porphyrin may be an oxoiron(IV) porphyrin $\pi$ cation radical or an iron-peroxo species. ${ }^{37,38}$

The efficiency of $\mathrm{Fe}\left(\mathrm{PCl}_{8}\right) \mathrm{Cl}$ to catalyse alkene and alkane oxidation with hydrogen peroxide was investigated in solution using cyclooctene and cyclohexane as substrates, in standard reaction conditions as defined for iodosylbenzene, which are similar of those used by Nam et al. ${ }^{36}$ In order to favour the heterolytic over the homolytic cleavage of $\mathrm{O}-\mathrm{O}$ bond to give the high valent oxoiron(IV) porphyrin $\pi$-cation radical the reactions were also carried out in the presence of imidazole and by the slow addition of the oxidant in small aliquots as suggested by Nam et $a l^{36}$. and others. ${ }^{39-}$ ${ }^{42}$ The results show that $\mathrm{Fe}\left(\mathrm{PCl}_{8}\right) \mathrm{Cl}$ is an ineffective catalyst for the oxidation of cyclooctene and cyclohexane if the oxidant is added in one aliquot at the start of the reaction (Table 7, entries 1 and 4). UV/Vis analysis of the solution after reaction showed that under these conditions the catalyst was partially or completed destroyed. This suggests that the hydrogen peroxide is homolytically cleaved to generate the potent oxidizing radical, HO, in a Fenton-type reaction and these attacks and destroys the porphyrin ring. When the reactions were repeated with the same amount of oxidant, added slowly in 4 aliquots, cyclooctene gave $24 \%$ of epoxide (Table 7 , entry 2) but no oxidation products were detected from cyclohexane (Table 7, entry 5). Monitoring the hydrogen peroxide concentration after reaction showed that more than $50 \%$ of unreacted oxidant was still present at the end of cyclooctene oxidation indicating that catalyst destruction (as confirmed by UV/Vis spectrum) may in part be responsible for the low epoxide yields. The presence of imidazole as co-catalyst led to a decrease in the epoxide yield (Table 7, entry 3 ). Only one imidazole binds to metal centre in $\mathrm{Fe}\left(\mathrm{PCl}_{8}\right)$, as noted from the titration data with this ligand, and the oxidant interaction with the iron centre would occur at the second axial position of the iron centre. However, this interaction is probably prevented by the greater steric hindrance around this axial site. This results in a competition between imidazole and hydrogen peroxide to bind to the iron porphyrin. For the cyclohexane, the presence of imidazole led to an increasing in product yields (Table 7 - entry 6). However, the low selectivity for hydroxylation indicates radical participation in this case.

A more detailed study of the intermediate species in these systems using UV/Vis and EPR spectroscopy is under investigation in our laboratory in order to better understand these mechanism oxidations.

\section{Conclusions}

The synthesis and use of the new third generation iron porphyrin $\mathrm{Fe}\left(\mathrm{PCl}_{8}\right) \mathrm{Cl}$, iron(III) 5-(pentafluorophenyl)10,15,20-tris(2,6-dichlorophenyl)- 2,3,7,8,12,13,17,18octachloroporphyrin as a catalyst in hydrocarbon oxidation is described and compared with it second generation analogue $\mathrm{Fe}(\mathrm{P}) \mathrm{Cl}$, iron(III) 5-(pentafluorophenyl)-10,15,20tris(2,6-dichlorophenyl)-porphyrin.

Although $\mathrm{Fe}\left(\mathrm{PCl}_{8}\right) \mathrm{Cl}$, is no more efficient for alkane epoxidation than analogues, $\mathrm{Fe}(\mathrm{P}) \mathrm{Cl}$, it is a superior catalyst for alkane hydroxylation. In alkane oxidation $\mathrm{Fe}\left(\mathrm{PCl}_{8}\right) \mathrm{Cl}$ shows a greater selectivity than $\mathrm{Fe}(\mathrm{P}) \mathrm{Cl}$ for less reacting / less hindered $\mathrm{C}-\mathrm{H}$ bonds arising from a more reactive / less hindered active oxidant.

When covalently bound to aminopropylated silica, $\mathrm{Fe}\left(\mathrm{PCl}_{8}\right) \mathrm{Cl}$ is less efficient as a catalyst than in solution, although it can readily be recovered and reused.

When hydrogen peroxide is used, in place of $\mathrm{PhIO}$, fast 
addition of the oxidant favours radical destruction of the catalyst. With more controlled addition of hydrogen peroxide, moderate yields of hydrocarbon oxidation are obtained.

\section{Acknowledgements}

Capes and FAPESP.

\section{References}

1. Groves, J. T.; Nemo, T. E.; Myers, R. S.; J. Am. Chem. Soc. 1979, 101, 1032.

2. Meunier, B.; Chem. Rev. 1992, 92, 1411.

3. Owanejko, R.; Battioni, P.; Mansuy, D.; Mlodnicka, T.; J. Mol. Catal. A: Chem. 1996, 111, 7.

4. Battioni, P.; Bartoli, J. F.; Mansuy, D.; Byun, Y. S.; Traylor, T. G.; J. Chem. Soc., Chem. Commun. 1991,1051.

5. Gross, Z.; Simkhovich, L.; Tetrahedron Lett. 1998, 39, 8171.

6. Cunningham, I. D.; Danks T. N.; Hay, J. N.; Hamerton, I.; Gunathilagan, S.; Janczak, C.; J. Mol. Catal. A: Chem. 2002, $185,25$.

7. Cunningham, I. D.; Danks T. N.; O`Connel, K.. T. A..; Scott, P. W.; J. Chem. Soc. Perkin Trans. 2 1999, 2133.

8. Doro F. G., Lindsay Smith, J. R.; Ferreira, A.. G.; Assis, M. D.; J. Mol. Catal. A: Chem. 2000, 164, 97.

9. Sharefkin, J. G.; Saltzman, H.; Org. Synth. 1963, 5, 658.

10. Kadish, K. M. ; Araulo-McAdms, C.; Han, B. C.; Franzen, M. M.; J. Am. Chem. Soc. 1990, 112, 8364.

11. Tellend, A.; Battioni, P.; Mansuy, D.; J. Chem. Soc., Chem. Commun. 1994, 1035.

12. Fleisher, E. B.; Fine, D. A.; Inorg. Chim. Acta 1978, 29, 267.

13. Hatano K.; Safo, M. K.; Walker A..; Scheidt, W. R.; lnorg. Chem. 1991, 30, 1643.

14. Balke V. L.; Waiker, F. A.; West J. T.; J. Am. Chem. Soc. 1985, 107, 1226.

15. Walker F. A.; Lo M. W.; Ree, M. T.; J. Am. Chem. Soc. 1976, 98, 5552.

16. Breaul, D., Rougee, M.; Biochem. Biophys. Res. Commun. 1974, 57, 654.

17. Brown, K.. L.; Inorg. Chim. Acta 1979, 37, L513.

18. Carrier M.; Scheer C.; Gouvine P.; Bartoli J. F.; Battioni, P.; Mansuy, D. Tetrahedron Lett. 1990, 31, 6645.

19. Rocha Gonsalves, A. M. A.; Johnstone, R. A. W.; Pereira, M. M.; Shaw, J.; Sobral, A. J. F. N.; Tetrahedron Lett. 1991, 32, 1355.

20. Mahy, J. P.; Battioni, P.; Mansuy, D.; J. Am. Chem. Soc. 1986 , $108,1079$.
21. Mahy, J. P.; Battioni, P.; Bedi G.; Mansuy D.; Fischer J.; Weiss, R.; Morgenstern-Badarau, I.; Inorg. Chem. 1988, 27, 353.

22. Chevrier, B.; Weiss, R.; Lange, M.; Chottardm, J. C.; Mansuy, D.; J. Am. Chem. Soc. 1981, 103, 2899.

23. Groves, J. T.; Watanabe Y.; J. Am. Chem. Soc. 1986,108. 7836.

24. Coyle, C. L..; Rafson, P. A.; Aboett, E. H.; Inorg. Chem. 1973, 12, 2007.

25. Manso, C. M. C. P., PhD. Thesis, Universidade de São Paulo, Brazil, 1998.

26. Manso, C. M. C. P.; Neri, C. R.; Vidoto, E. A.; Sacco, H. C.; Ciuffi, K. J.; Iwamoto, L. S.; Iamamoto, Y.; Nascimento, O. R.; Serra, O. A.; J. Inorg. Biochem. 1999, 73, 85.

27. Hatano, K.; Safo, M. K.; Walker, A..; Scheidt, W. R.; Inorg. Chem. 1991, 301643.

28. Latos-Grazynski, L..; Cheng, R.; La Mar, G. N.; Balch, A. L.; J. Am. Chem. Soc. 1981, 103, 4270.

29. Assis, M. D.; Lindsay Smith, J. R.; J. Chem. Soc. Perkin Trans. 1998, 2221.

30. Ozette, K.; Battioni, P.; Leduc, P.; Bartoli, J. F.; Mansuy, D.; Inorg. Chim. Acta 1998, 4, 272.

31. Bartoli, J. F.; Brigaud, O.; Battioni, P.; Mansuy, D.; J. Chem. Soc., Chem. Commun. 1991, 440.

32. Murakami, T.; Yamaguechi, K.; Watanabe, Y.; Morishima, I.; Bull. Chem. Soc. Jpn. 1998, 71, 1343.

33. Traylor, T. G.; Tsuchiya, S.; Byun, Y. S.; Kim, C.; J. Am. Chem. Soc. 1993, 115, 2775.

34. Traylor, T. G.; Fann, W. P.; Bandyopadhyay, D.; J. Am. Chem. Soc. 1989, 111, 8009.

35. Nam, W.; Cheal, K.; Lim, M. H.; Lee Y. J.; Goh, M. Y.; Bull. Chem. Soc. Jpn. 1999, 72, 707.

36. Nam, W.;Lee, H. J.; Young, O.; Cheal, S. K.; Jang, H. G.;J. Inorg. Bioch. 2000, 80, 219.

37. Nam, W.; Han, H. J.; Oh, S. Y.; Lee, J.; Choi, M.; Shin, S. W.; J. Am. Chem. Soc. 2000, 122, 8677.

38. Nam, W.; Goh,Y. M.; Lee, Y. J.; Lim, M. H.; Kim, C.; Inorg. Chem. 1999, 38, 3238.

39. Harris, D. L.; Loew, G. H.; J. Porphyrins Phthalocyanines 2001, 5, 334 .

40. Fujii, H.; Yoshimura, T.; Kamada, H.; Inorg. Chem. 1997, 36, 6142 .

41. Fujii, H.; Coord. Chem. Rev. 2002, 226, 51.

42. Nam, W.; Lim, M. H.; Oh, S.; Lee, J. H.; Woo, S. K,; Kim, C.; Shin, W.; Angew. Chem. Int. 2000, 39, 3646.

Received: August 11, 2004

Published on the web: June 17, 2005

FAPESP helped in meeting the publication costs of this article. 